\title{
Critical review of health effects of soyabean phyto-oestrogens in post-menopausal women
}

\author{
Aedin Cassidy ${ }^{1 *}$, Paola Albertazzi ${ }^{2}$, Inge Lise Nielsen ${ }^{3}$, Wendy Hall ${ }^{4}$, Gary Williamson $^{3}$, Inge Tetens ${ }^{5}$, \\ Steve Atkins ${ }^{2}$, Heide Cross ${ }^{6}$, Yannis Manios ${ }^{7}$, Alicja Wolk ${ }^{8}$, Claudia Steiner ${ }^{9}$ and Francesco Branca ${ }^{10}$ \\ ${ }^{1}$ School of Medicine, Health Policy and Practice, University of East Anglia, Norwich NR4 7TJ, UK \\ ${ }^{2}$ Centre for Metabolic Bone Disease, Hull Royal Infirmary, Hull HU3 2RW, UK \\ ${ }^{3}$ Nestlé Research Center, Vers Chez Les Blanc, Lausanne, Switzerland \\ ${ }^{4}$ School of Food Biosciences, University of Reading, Reading RG6 6AP, UK \\ ${ }^{5}$ Department of Nutrition, Institute for Food and Agricultural Research, Sфborg, Denmark \\ ${ }^{6}$ Department of Pathophysiology, Medical University of Vienna, Vienna, Austria \\ ${ }^{7}$ Department of Nutrition and Dietetics, Harokopio University, Kallithea-Athens, Greece \\ ${ }^{8}$ The National Institute of Environmental Medicine, Karolinska Institutet, Stockholm, Sweden \\ ${ }^{9}$ Institute of Nutrition, Friedrich-Schiller University of Jena, Jena, Germany \\ ${ }^{10}$ National Institute for Research and Food and Nutrition (INRAS), via Ardeatria 546, 00178 Roma, Italy
}

\begin{abstract}
A consensus view of soyabean phyto-oestrogens in clinical interventions in post-menopausal women is presented that is based on data from the EU-funded project Phytohealth. The phytooestrogens, primarily genistein and daidzein, were given as soyabean-protein isolates, wholesoyabean foods or extracts, supplements or pure compounds. A comprehensive literature search was conducted with well-defined inclusion or exclusion criteria. For areas for which substantial research exists only placebo-controlled double-blind randomised controlled trials (RCT) conducted on healthy post-menopausal women were included. For emerging areas all available human studies in post-menopausal women were reviewed. In order to make cross comparisons between studies the doses of isoflavones were calculated as aglycone equivalents. There is a suggestion, but no conclusive evidence, that isoflavones from the sources studied so far have a beneficial effect on bone health. The consumption of whole-soyabean foods and soyabeanprotein isolates has some beneficial effects on lipid markers of cardiovascular risk. The consumption of isolated isoflavones does not affect blood lipid levels or blood pressure, although it may improve endothelial function. For menopausal symptoms there is currently limited evidence that soyabean-protein isolates, soyabean foods or red-clover (Trifolium pratense L.) extract are effective but soyabean isoflavone extracts may be effective in reducing hot flushes. There are too few RCT studies to reach conclusions on the effects of isoflavones on breast cancer, colon cancer, diabetes or cognitive function. The health benefits of soyabean phytooestrogens in healthy post-menopausal women are subtle and even some well-designed studies do not show protective effects. Future studies should focus on high-risk post-menopausal women, especially in the areas of diabetes, CVD, breast cancer and bone health.
\end{abstract}

Genistein: Daidzein: Bioavailability: Bone health: CVD

The current interest in soyabean and its phyto-oestrogen component in relation to human health has resulted in a substantial number of publications on the potential clinical efficacy of these compounds to improve health in menopausal women. However, although numerous reviews have been presented, to date a consensus on the potential importance of these compounds for menopausal health following a critical grading of the studies and their results has not been conducted. The focus of the current review is specifically to grade the evidence from clinical studies addressing the effects of intervention of soyabean isoflavones (for chemical structures of the aglycones, see 
<smiles></smiles>

Daidzein<smiles>O=c1c(-c2ccc(O)cc2)coc2cc(O)cc(O)c12</smiles>

Genistein<smiles>Oc1ccc(C2COc3cc(O)ccc3C2)cc1</smiles><smiles>COc1ccc(-c2coc3cc(O)ccc3c2=O)cc1</smiles>

Formononetin<smiles>COc1ccc(-c2coc3cc(O)cc(O)c3c2=O)cc1</smiles>

Biochanin A

Fig. 1. A comparison of the chemical structures of isoflavone metabolites and the gut metabolite equol.

Fig. 1) fed as soyabean-protein isolates (SPI), wholesoyabean foods or extracts, supplements or pure compounds and reach a consensus on optimal dose, food source and duration of use for each of the health outcomes. This procedure will be conducted in depth for bone health, CVD and menopausal symptoms and current knowledge summarised for other areas of growing interest, including cancer, cognition and diabetes. The comparability of clinical studies is confounded by the variability in phytooestrogen composition and dose administered in the intervention studies. Thus, before reviewing the health effects the available evidence on factors influencing the bioavailability of isoflavones will be reviewed, since the intervention studies have used different doses and sources of isoflavones to examine the various health effects.

The consensus view presented is based on data from the EU-funded project Phytohealth, a pan-European network of excellence funded by the EU (QLKII-CT-2002-02453), which has brought together a multidisciplinary team of scientists, including toxicologists, clinicians and nutritionists to evaluate the current research in the phytooestrogens field and identify current gaps in knowledge.

\section{Materials and methods}

A literature search was conducted (up to June 2005) using MEDLINE (PubMed), EMBASE and the Cochrane
Collaboration (The Cochrane Library). The search included the following keywords: phytoestrogens, isoflavones, genistein, daidzein, equol, soy (a); cross-referenced with the key words: post-menopausal, hot flushes, osteoporosis, bone mineral density, bone metabolism, cardiovascular, endothelial function, vascular reactivity, blood pressure, lipid profile, breast, colon, cognition.

In order to make cross comparisons between studies that used a range of sources of isoflavones the doses of isoflavones were calculated as aglycone equivalents. A panel of Phytohealth members reviewed the studies and classified them according to the grading criteria proposed by Harbour \& Miller (2001; Table 1).

For areas in which substantial research has been conducted only studies with a high grade $(\geq 1+)$ have been considered in the formulation of the consensus statement. Only placebo-controlled double-blind randomised controlled trials (RCT) conducted on healthy women $>1$ year post-menopausal (for hot flushes $>6$ months and biochemically defined) were included. Evaluation of methodological strength was conducted following the methodology outlined by Jadad et al. (1996). In particular, absence of bias, quality of data collection, quality of reporting of study methodology, adequate power calculations, clear characterisation of dose and composition of phyto-oestrogen product were considered. Additional inclusion criteria were applied for each specific health outcome. For bone health only studies with a duration $\geq 6$

Table 1. Grading criteria applied to the studies assessed in the present review

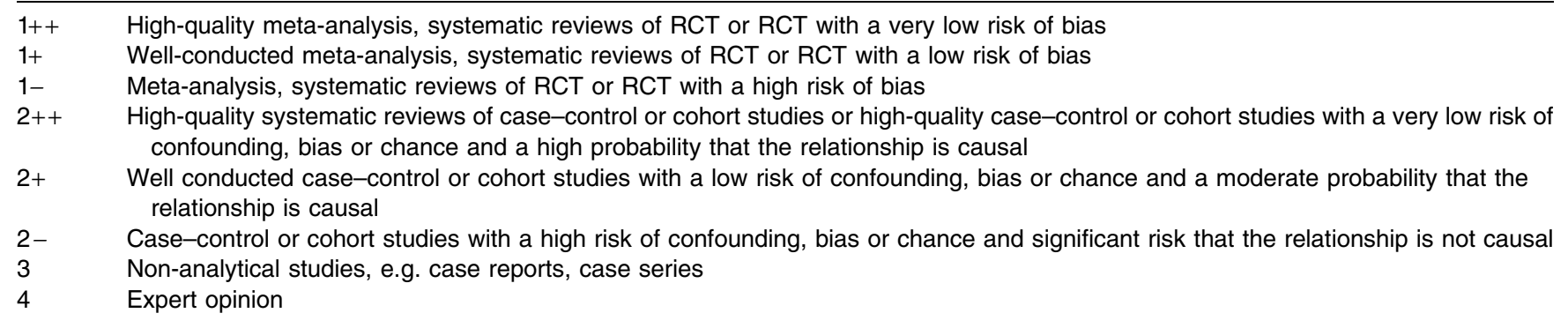

$\mathrm{RCT}$, randomised controlled trials. 
Table 2. Grading methodology applied to the studies (from Agency for Health Care Policy and Research, 1992)

A At least one meta-analysis systematic review or at least one RCT 1++ performed on the target population; alternatively, a systematic
review of RCT or collection of evidences from studies of $1+$ offering consistent evidence and with outcomes directly applicable to
the target population
Evidence that can be classified of level $2++$, which is consistent and with outcomes directly applicable to the target population;
alternatively, evidence that can be extrapolated from studies $1++$ or $1+$ not directly applicable to the target population
B Evidence that can be classified of level $2+, 2++$, which is consistent and with outcomes directly applicable to the target population;
alternatively, evidence that can be extrapolated from studies $2++$ not directly applicable to the target population
C Evidence of level 3 or 4 , or evidence extrapolated from studies of level $\leq 2+$
D
GPP pood practice point; on the basis of expert opinion, not supported by experimental evidence

$1++, 1+, 2++, 2+, 3,4$, levels of grading applied to the studies (for details of criteria, see Table 1); RCT, randomised controlled trials.

months were included, and for cardiovascular health and menopausal symptoms only studies with a duration $\geq 4$ weeks were included. For menopausal symptoms only studies purposefully designed for this outcome were included.

For emerging areas, including cognitive function, breast and colo-rectal health and diabetes, all available human studies in post-menopausal women (or mixed menopausal status studies) were considered and reviewed (level of evidence of $2+$ and above). All papers reviewed by the panel were tabulated, with the studies that matched the criteria for inclusion in the consensus paper presented within the text. The panel then weighted the evidence and a statement was formulated for each health effect and assigned a grade, based on the quality of the studies used. Grading was assigned according to the methodology outlined in Table 2 (Agency for Health Care Policy and Research, 1992).

\section{Results and discussion}

Bioavailability and sources

The importance of understanding factors influencing absorption and metabolism as these factors may influence potential clinical effects under study. During the course of studies on health effects the isoflavone test compounds are consumed in various forms, together with other foods, in various doses and by different age-groups. All these variables could influence the bioavailability and therefore the final outcome of the study. This section examines how the outcome of human intervention studies could be affected, either positively or negatively, by bioavailability factors. Examination of the data (Tables 4-10) reveals that a range of sources of isoflavones has been used: pure compound (tablets or capsules), extracts of soyabean germ or red clover (Trifolium pratense L.), soyabean flour, soya beverages, isoflavone-enriched soyabean protein, soyabean-protein drinks or SPI. Many of the studies were long term and during each study the overall diet was not fully monitored, implying that the effect of foods on bioavailability also needs to be considered.

Variables in isoflavone bioavailability: food matrix and storage. One of the most important factors is to measure the amount of isoflavone in the food or supplement at the moment of consumption, since storage and processing influence the amount of isoflavone in the final product and the stability of the various isoflavones is different depending on the structure (Mahungu et al. 1999; Xu et al. 2002; Eisen et al. 2003; Lee et al. 2003). Other factors in the diet, such as fibre, can also affect the bioavailability (Tew et al. 1996). The source of the isoflavones and hence the food matrix in which the compound is delivered seems to be less important, and generally studies have found no difference in the bioavailability between cooked soyabeans, textured vegetable protein, tofu or tempeh $(\mathrm{Xu}$ et al. 2000) or soya-milk powder or soyabean germ (Zheng et al. 1999).

Variables in isoflavone bioavailability: chemical nature of the isoflavone. The chemical form of the isoflavone may affect the bioavailability, and there is some evidence to suggest that bioavailability is different following consumption of fermented soyabean products (containing mainly aglycones) compared with ingestion of nonfermented soyabean products (containing the naturallyoccurring isoflavone glucosides (Izumi et al. 2000; Setchell et al. 2001)). This aspect of aglycone $v$. glycoside is an important factor in designing an intervention study. The pharmaco-kinetic values from sixteen studies are shown in Table 3 . There is a linear increase in peak mean plasma concentration for daidzein between 1 and $31 \mu \mathrm{mol} / \mathrm{kg}$ body weight $\left(\mathrm{R}^{2} 0.958\right)$ and for genistein between 0.2 and $59 \mu \mathrm{mol} / \mathrm{kg}$ body weight $\left(\mathrm{R}^{2} 0 \cdot 974\right)$. There is also a correlation, although weaker, for the glucosides $\left(R^{2} 0.716\right.$ and $\mathrm{R}^{2} 0.730$ respectively). The area under the curve, urinary excretion and faecal excretion show no significant correlations with dose for any of the compounds between the selected studies.

Variables in isoflavone bioavailability: effect of age. No difference has been found in the pharmaco-kinetics of either genistein or daidzein between pre- and postmenopausal women (Setchell et al. 1997, 2003a; Lu \& Anderson, 1998; Faughnan et al. 2004).

Variables in isoflavone bioavailability: frequency of ingestion. No significant differences have been observed in the pharmaco-kinetics of $\left[{ }^{13} \mathrm{C}\right]$ daidzein or $\left[{ }^{13} \mathrm{C}\right]$ genistein after 2 weeks wash-out or after $7 \mathrm{~d}$ of soyabean consumption (Setchell et al. 2003b). After 1 month of daily soyamilk feeding there is a decrease in the urinary excretion of genistein and daidzein, whereas that of equol increases; however, this effect is only detected in women and not in men (Lu \& Anderson, 1998).

Metabolism as a confounder or additional variable in efficacy studies: equol production. The ability to convert daidzein to equol is observed in about $30-50 \%$ of individuals. An analysis by Setchell et al. (2002a) has shown that 
Table 3. Pharmaco-kinetic data for daidzein, genistein and their glucosides from sixteen published studies (Values are presented as the average of all studies and the range)

\begin{tabular}{|c|c|c|c|c|c|c|c|c|c|c|}
\hline & \multirow[b]{2}{*}{$c_{\max }^{*}(\mu M)$} & \multicolumn{2}{|c|}{$t_{\max }(h)$} & \multicolumn{2}{|c|}{$t_{1 / 2}(h)$} & \multirow[b]{2}{*}{$\operatorname{AUC}^{\star}(\mu \mathrm{m} / \mathrm{h})$} & \multicolumn{2}{|c|}{ Urinary excretion (\%) } & \multicolumn{2}{|c|}{ Faecal excretion (\%) } \\
\hline & & $A v$ & Range & $A v$ & Range & & $A v$ & Range & Av & Range \\
\hline Daidzein & 0.54 & $6 \cdot 2$ & $4 \cdot 0-8 \cdot 3$ & $7 \cdot 7$ & $4 \cdot 2-16$ & $18 \dagger$ & $34 \dagger$ & $26-50$ & & \\
\hline Genistein & 0.49 & $5 \cdot 7$ & $3 \cdot 5-9 \cdot 3$ & 9.5 & $6 \cdot 1-17$ & $11 \dagger$ & $11 \dagger$ & $8 \cdot 3-18$ & & \\
\hline Daidzin & 0.77 & $7 \cdot 5$ & $5 \cdot 5-9 \cdot 2$ & $7 \cdot 0$ & $4 \cdot 6-9.5$ & 6 & $50 \dagger$ & $15-56$ & $3 \cdot 7 \dagger$ & $0.6-5.5$ \\
\hline Genistin & 0.97 & $6 \cdot 7$ & $4 \cdot 0-9 \cdot 3$ & 9.5 & $5 \cdot 7-18$ & $16 \dagger$ & $19 \dagger$ & $5 \cdot 3-39$ & $3.0 \dagger$ & $0.5-8.6$ \\
\hline
\end{tabular}

Av, average; $c_{\max }$, peak mean plasma concentration; $t_{\max }$, time to reach maximum plasma concentration; $t_{1 / 2}$, half-life; AUC, area under curve. ${ }^{*}$ Average values after ingestion of $1 \mu \mathrm{mol} / \mathrm{kg}$ body weight.

†High uncertainty on value as a result of large variance between studies.

the ability to produce equol is associated with an increased benefit of isoflavones on bone mineral density. Equol production is influenced by intestinal microflora composition, gut transit time and the redox potential of the colon (Setchell et al. 1984). During the first months of life the plasma and urine levels of equol are lower than those in adults, probably because of an immature gut flora (Setchell et al. 1997). Ingestion of daidzin results in a higher equol production than after ingestion of the aglycone daidzein alone (Setchell et al. 1997; Lampe et al. 1998; Zubik \& Meydani, 2003), and equol production is more prevalent in subjects with a high consumption of carbohydrates and dietary fibre and a low dietary fat:fibre (Lampe et al. 1998; Watanabe et al. 1998; Rowland et al. 1999).

Metabolism as a confounder or additional variable in efficacy studies: chemical forms in the plasma. In most subjects the plasma curves for isoflavones show a double peak consisting of a sharp early peak followed by a later larger and more rounded peak, representing a combination of entero-hepatic recycling, together with absorption in the duodenum-jejunum followed by (higher) absorption in the colon (King \& Bursill, 1998; Setchell, 1998; Day et al. 2000). Isoflavones are deconjugated during absorption (Day et al. 2000; Setchell et al. 2002b; Wilkinson et al. 2003) and are found in plasma as conjugates of sulfate and glucuronic acid. Genistein glucuronide exhibits a later time to reach maximum plasma concentration than genistein sulfate, daidzein sulfate and daidzein glucuronide, and both genistein conjugates show a longer half-life than the corresponding daidzein conjugates (Shelnutt et al. 2002). The frequency of isoflavone consumption has no effect on the proportion of glucuronides, sulfates and aglycones of genistein and daidzein in plasma or urine (Zhang et al. 2003). The relative biological activities of the isoflavone conjugates in the plasma are dependent on the chemical structure (Turner et al. 2004).

Bioavailability in human intervention studies. It can be concluded that understanding the bioavailability of the isoflavones in a given foodstuff is essential before embarking on a study of the clinical effects. Most importantly, it is essential to measure accurately the amount and form of isoflavones at the point of consumption during the study, and to check this information at regular intervals. Taken together, factors such as glycoside $v$. aglycone, food source, the 'equol producer' state of the volunteers and the influence of other foods eaten during the study can determine whether a significant biological or clinical effect is observed, or not.

\section{Health effects: bone}

Consensus statement for effects on bone: grade A recommendation. As a result of limited relevant studies and differences in methodological approaches there is a suggestion, but no conclusive evidence, that isoflavones from the sources studied so far have a beneficial effect on bone health. A recommendation cannot therefore be made at the current time and there is a need for further highquality long-term ( $>1$ year) studies to clarify the effect of phyto-oestrogens on bone.

Summary of data for bone health. Bone health is a major concern as women age, and femur or vertebral fractures may severely affect the quality of life. Hormonereplacement therapies have been the first line of treatment of hormone-related osteoporosis, but major side effects preclude their universal use. The observation that SouthEast Asian women report a lower occurrence of osteoporosis has led to the hypothesis that soyabean or soyabean phyto-oestrogens are a possible alternative option for the prevention of osteoporosis. Thirty-one studies have examined the effects of phyto-oestrogens on bone mass or bone turnover, or both, but only six studies met the inclusion criteria (Potter et al. 1998; Clifton-Bligh et al. 2001; Morabito et al. 2002; Chen et al. 2003; Gallagher et al. 2004; Kreijkamp-Kaspers et al. 2004; Table 4). Three of these studies used pure compounds or extracts and three studies provided foods containing soyabean protein or SPI.

Of the three studies that used soyabean isoflavone extracts or pure genistein, two are suggestive of an effect on bone mineral density at doses ranging from 35 to $54 \mathrm{mg}$ aglycone equivalents. Only one of the three studies performed with SPI shows an effect on bone mineral density at a dose of $56 \mathrm{mg}$ aglycone equivalents, while the two other studies show no effect with doses ranging from 4 to $103 \mathrm{mg}$ aglycone equivalents. The age since menopause does not appear to influence the effect of phyto-oestrogens on bone mineral density or bone mineral content in all studies.

Only three of the identified studies included biomarkers of bone formation or bone resorption. One study, which used SPI (Gallagher et al. 2004), shows no effect on bone markers, and the study that used genistein $(54 \mathrm{mg})$ shows 
Table 4. Effects of soyabean isoflavones on bone biomarkers and bone density

\begin{tabular}{|c|c|c|c|c|c|c|c|c|}
\hline Reference & $\begin{array}{c}\text { Age } \\
(\text { (years })^{*}\end{array}$ & $\begin{array}{l}\text { Subjects } \\
\text { completed }\end{array}$ & $\begin{array}{l}\text { Study } \\
\text { design }\end{array}$ & $\begin{array}{l}\text { Duration } \\
\text { (months) }\end{array}$ & $\begin{array}{l}\text { Isoflavone } \\
\text { source }\end{array}$ & $\begin{array}{l}\text { Daily dose } \\
\text { (mg aglycone } \\
\text { equivalents) }\end{array}$ & $\begin{array}{c}\text { Bone } \\
\text { biomarkers }\end{array}$ & $\begin{array}{l}\text { Bone } \\
\text { density }\end{array}$ \\
\hline \multicolumn{9}{|l|}{ Soyabean protein } \\
\hline $\begin{array}{l}\text { Gallagher et al. } \\
(2004)\end{array}$ & $\begin{array}{l}40-62 \\
55 \text { (SD 1) }\end{array}$ & 50 & $\mathrm{~Pa}$ & 9 & SPI & $2,32,60$ & $\begin{array}{l}\text { BF (BGP, BALP) no } \\
\text { effect BR (NTx) } \\
\text { no effect }\end{array}$ & No effect \\
\hline Potter et al. (1998) & $49-83$ & 66 & $\mathrm{~Pa}$ & 6 & SPI & 35,56 & NA & $\begin{array}{l}56 \mathrm{mg}: \uparrow 2 \cdot 2 \% \text { for } \\
\text { BMD for lumbar } \\
\text { spine; } \\
35 \mathrm{mg}: \text { no effect }\end{array}$ \\
\hline $\begin{array}{l}\text { Kreijkamp-Kaspers } \\
\text { et al. (2004) }\end{array}$ & $60-75$ & 175 & $\mathrm{~Pa}$ & 12 & SPI & 99 & NA & No effect \\
\hline \multicolumn{9}{|l|}{ Isoflavone extracts } \\
\hline Chen et al. (2003) & $48-62$ & 175 & $\mathrm{~Pa}$ & 12 & $\begin{array}{l}\text { Soyabean } \\
\text {-germ } \\
\text { extract }\end{array}$ & 25,50 & NA & $\begin{array}{l}50 \mathrm{mg}: \text { no effect on } \\
\text { BMD; } \uparrow 0.5 \% \text { for } \\
\text { BMC for total hip } \\
\text { and trochanter; } \\
25 \mathrm{mg} \text { : no effect }\end{array}$ \\
\hline $\begin{array}{l}\text { Clifton-Bligh et al. } \\
\text { (2001) }\end{array}$ & 57 (SD 5) & 46 & $\mathrm{~Pa}$ & 6 & $\mathrm{RC}$ extract & $17,35,53$ & $\begin{array}{l}\text { BR (fDPD): no } \\
\text { effect }\end{array}$ & $\begin{array}{l}53 \mathrm{mg}: \uparrow 3 \% \text { for } \\
\text { BMD for proximal } \\
\text { radius and ulna } \\
35 \mathrm{mg}: \uparrow 4 \cdot 1 \% \text { for } \\
\text { BMD for proximal } \\
\text { radius and ulna } \\
17 \mathrm{mg}: \text { no effect }\end{array}$ \\
\hline $\begin{array}{l}\text { Morabito et al. } \\
\text { (2002) }\end{array}$ & $47-57$ & 90 & $\mathrm{~Pa}$ & 12 & Genistein & 54 & $\begin{array}{c}\uparrow B F(B G P, B A L P) \downarrow \\
\text { BR (fPyd, fDpd) }\end{array}$ & $\begin{array}{c}\uparrow 3 \% \text { for BMD for } \\
\text { hip and spine }\end{array}$ \\
\hline
\end{tabular}

$\mathrm{Pa}$, parallel; BF, bone formation; BGP, bone Gla protein (osteocalcin); BALP, bone alkaline phosphatase; BR, bone resorption; NTx, urinary N telopeptide; NA, not available; BMD, bone mineral density; BMC, bone mineral content; fPyd, free pyridinoline; fDPD, free deoxypyridinoline; SPI, soyabean-protein isolate; RC, red clover (Trifolium pratense $\mathrm{L}$ ); $\uparrow$, increase; $\downarrow$, decrease.

*Values shown are ranges and/or means and standard deviations.

an increase in bone formation biomarkers and a reduction in bone resorption biomarkers.

\section{Health effects: cardiovascular effects}

Consensus statement for cardiovascular effects: grade A recommendation. On the basis of the available evidence, the panel has concluded that the consumption of whole-soyabean foods and SPI has some beneficial effects on lipid markers of cardiovascular risk in healthy postmenopausal women. The consumption of isolated isoflavones does not affect blood lipid levels or blood pressure, although it may improve endothelial function.

Adequately-powered human intervention studies that can definitively establish the benefits of either encapsulated isoflavones or isoflavone-fortified foods are needed, particularly in women at high risk.

Summary of data for cardiovascular effects. Epidemiological evidence from human subjects suggests that high soyabean consumption, the main dietary source of isoflavones, is cardioprotective. To date the predominant interest has been in relation to the hypercholesterolaemic effects, stimulated by the significant lipoprotein effects observed in the meta-analysis of Anderson et al. (1995). More recently, two further meta-analyses have investigated the effects of soyabean foods, soyabean protein and soyabean-isoflavone extracts on serum lipids (Weggemans \& Trautwein, 2003; Yeung \& Yu, 2003). In a meta-analysis of seventeen randomised trials (Yeung \& Yu, 2003) it has been found that isoflavone extracts (encapsulated) have no effects on serum lipids. Furthermore, since the studies of soyabean foods and SPI were heterogeneous in design and not statistically well-powered it is, therefore, not possible to draw conclusions on the lipid-lowering benefits of isoflavones contained in soyabean. Weggemans \& Trautwein (2003) have analysed the independent effects of soyabeanassociated isoflavones on plasma LDL- and HDLcholesterol in ten randomised controlled studies and have concluded that differences in isoflavone content of soyabean protein are not associated with concentrations of these lipoproteins. Thus, currently, there is uncertainty about extent of the contribution of soyabean isoflavones to the cholesterol-lowering effects that are reported in controlled trials of soyabean and soyabean products. However, data from in vitro and animal experiments are emerging that suggests that isoflavones may be cardioprotective by mechanisms independent of blood lipids (see review, Hall et al. 2004), but these underlying mechanisms are only partly understood. As a result, more recently, attention has focused on the potential effects of phyto-oestrogens on blood pressure, in vivo measures of vascular function such as flow-mediated dilation and novel biomarkers of CVD risk, and to date these studies have not been systematically reviewed.

Of the sixty-three studies conducted to date forty studies have used soyabean foods or soyabean-protein extracts or 
SPI and twenty-three have used isoflavone extracts from soyabean or other sources (e.g. red clover). Following grading of evidence three soyabean food studies, thirteen SPI studies and fifteen isoflavone-extract studies were included for further review. These data suggest that soyabean food and soyabean protein interventions may have a beneficial effect on lipoprotein status (Table 5), while there is limited data to support a lipid-lowering effect of isoflavone extracts. The data on the effects of soyabean foods and soyabean protein on blood pressure are equivocal, but it is clear that there is no evidence for an effect of isoflavone extracts on blood pressure.

Although there is growing interest in the potential direct effects of isoflavones on the arterial wall, only limited studies matching the present criteria have been conducted to date and the available data are inconclusive (Table 6). Increased flow-mediated dilation (Cuevas et al. 2003), decreased brachial artery peak flow velocity (Steinberg et al. 2003) and improved peripheral vascular resistance (Teede et al. 2001) have been demonstrated following soyabean protein, although not all studies are in agreement in their findings (Blum et al. 2003b). Some isoflavone extract studies have found positive effects on in vivo endothelial function measurements (Nestel et al. 1997, 1999; Squadrito et al. 2002, 2003; Teede et al. 2003). Other studies, however, have found no effect of isoflavones on in vivo endothelial function (Simons et al. 2000; Lissin et al. 2004). Other, more novel, biomarkers of CVD risk have been assessed in some studies included in the present analysis, such as inflammatory factors, coagulatory and fibrinolytic factors and markers of LDL oxidation (Table 7; Jenkins et al. 2002; Steinberg et al. 2003; Krebs et al. 2004; Hall et al. 2005; Teede et al. 2005). However, the number of these studies is very low and no conclusions can be drawn from the data available to date.

\section{Health effects: climacteric symptoms}

Consensus statement on climacteric symptoms: grade A recommendation. There is currently limited evidence that SPI, soyabean foods or red-clover extract are effective in reducing menopausal symptoms. Soyabean-isoflavone extracts may be effective in reducing hot flushes but

Table 5. An overview of the effects of different soyabean products on lipoprotein status and blood pressure in post-menopausal women $^{*}$

(The values represent the relative no. of trials showing an effect)

\begin{tabular}{lcc}
\hline Soyabean product & Lipoprotein status & Blood pressure \\
\hline Soya foods & $3 / 3$ & $0 / 1$ \\
Soyabean protein & $9 / 13$ & $2 / 3$ \\
Isoflavone extracts & $2 / 12$ & $0 / 5$ \\
\hline
\end{tabular}

*Trials reviewed: Atkinson et al. (2004a); Blum et al. (2003a,b); Campbell et al. (2004); Cuevas et al. (2003); Desroches et al. (2004); Dewell et al. (2002); Gardner et al. (2001); Han et al. (2002); Hodgson et al. (1998, 1999a,b); Howes et al. (2000); Lichtenstein et al. (2002); Lissin et al. (2004); Mackey et al. (2000); Nestel et al. (1997, 1999); Nikander et al. (2003);

Puska et al. (2002); Simons et al. (2000); Squadrito et al. (2002, 2003); Steinberg et al. (2003); Teede et al. (2001, 2003, 2005); Vigna et al. (2000); Wangen et al. (2001); Washburn et al. (1999). the effect is about half that observed with hormonereplacement therapy and similar to that of other nonhormonal pharmacological therapies.

Summary of data for climacteric symptoms. Epidemiological evidence suggests that there is wide international variability in the reporting of menopausal symptoms. In particular, populations consuming soyabean as a staple have a substantially reduced incidence compared with Western populations (Lock, 1993). Three systematic reviews on the effects of isoflavones and other herbal remedies on menopausal symptoms have so far been published (Huntley \& Ernst, 2003, 2004; Krebs et al. 2004). However, one review suggests some efficacy of soyabean preparations (Huntley \& Ernst, 2004), the second does not support the hypothesis that isoflavones from a range of sources improve menopausal symptoms (Krebs et al. 2004), while the third focuses on reviewing trials using herbal remedies but only includes red clover as a source of isoflavones (Huntley \& Ernst, 2003). The effects of all sources of phyto-oestrogens on menopausal symptoms were therefore further evaluated using the criteria set out earlier (Table 8). The main outcome measure in the studies was the change in the number of hot flushes following intervention, which was either qualitatively assessed (e.g. using the Kupperman (1953) or Greene (1998) climacteric scale) or quantified using diaries. Some of the studies also quantified the effects of phyto-oestrogen sources on the vaginal mucous, either subjectively by questioning the subject's perception of vaginal dryness or objectively using a vaginal maturation index (as a measure of oestrogenicity).

In total, twenty-four studies have examined the effect of phyto-oestrogens on the incidence and severity of hot flushes in peri- and post-menopausal women. Following review only sixteen studies met the inclusion criteria (Table 8). Four of these studies used SPI (Albertazzi et al. 1998; Kotsopoulos et al. 2000; Knight et al. 2001; St Germain et al. 2001) in doses ranging from 28 to $85 \mathrm{mg}$ aglycone equivalent (duration range 3-6 months), of which three have observed no effects on the incidence of hot flushes or vaginal dryness (Kotsopoulos et al. 2000; Knight et al. 2001; St Germain et al. 2001). Only one of the four studies has reported a decrease in hot flushes (Albertazzi et al. 1998) and only one study has reported a beneficial effect on vaginal dryness (Kotsopoulos et al. 2000). The study that used a soyabean beverage has reported no change in menopausal symptoms following intervention (Van Patten et al. 2002). Three studies using red clover as a source of isoflavones have indicated no effect either on the incidence of hot flushes or vaginal epithelial cell maturation (Baber et al. 1999; Knight et al. 1999; van de Weijer \& Barentsen, 2002). Seven studies have been performed using isolated isoflavones at doses ranging from 32 to $72 \mathrm{mg}$ aglycones equivalents/d (Scambia et al. 2000; Upmalis et al. 2000; Faure et al. 2002; Han et al. 2002; Nikander et al. 2003; Penotti et al. 2003; Petri Nahas et al. 2004) and one using purified genistein (Crisafulli et al. 2004). Six of the studies have observed a significant reduction in the occurrence of hot flushes (Scambia et al. 2000; Upmalis et al. 2000; Faure et al. 2002; Han et al. 2002; Crisafulli et al. 2004; Petri Nahas et al. 2004), but 


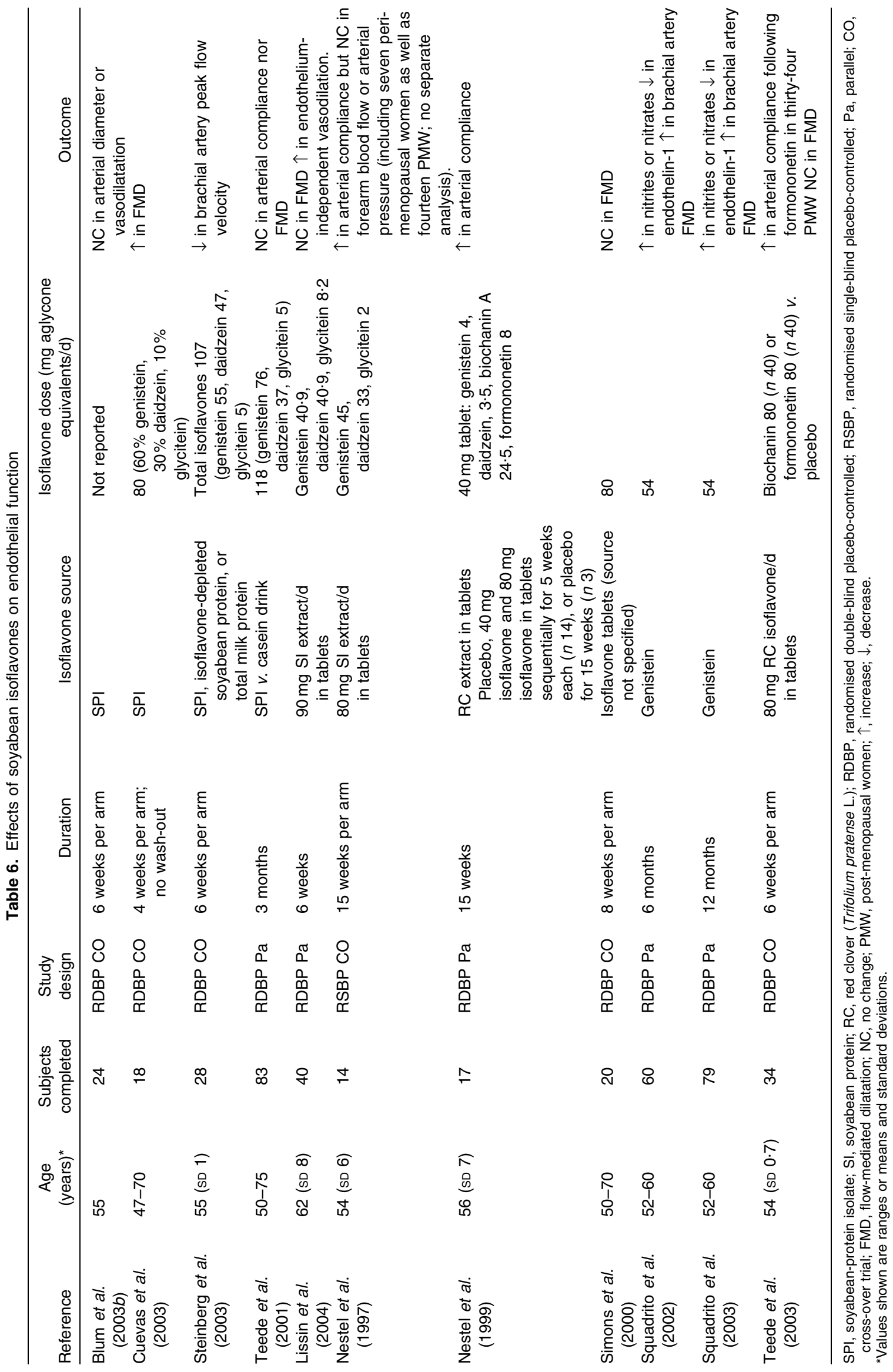


Phytochemicals

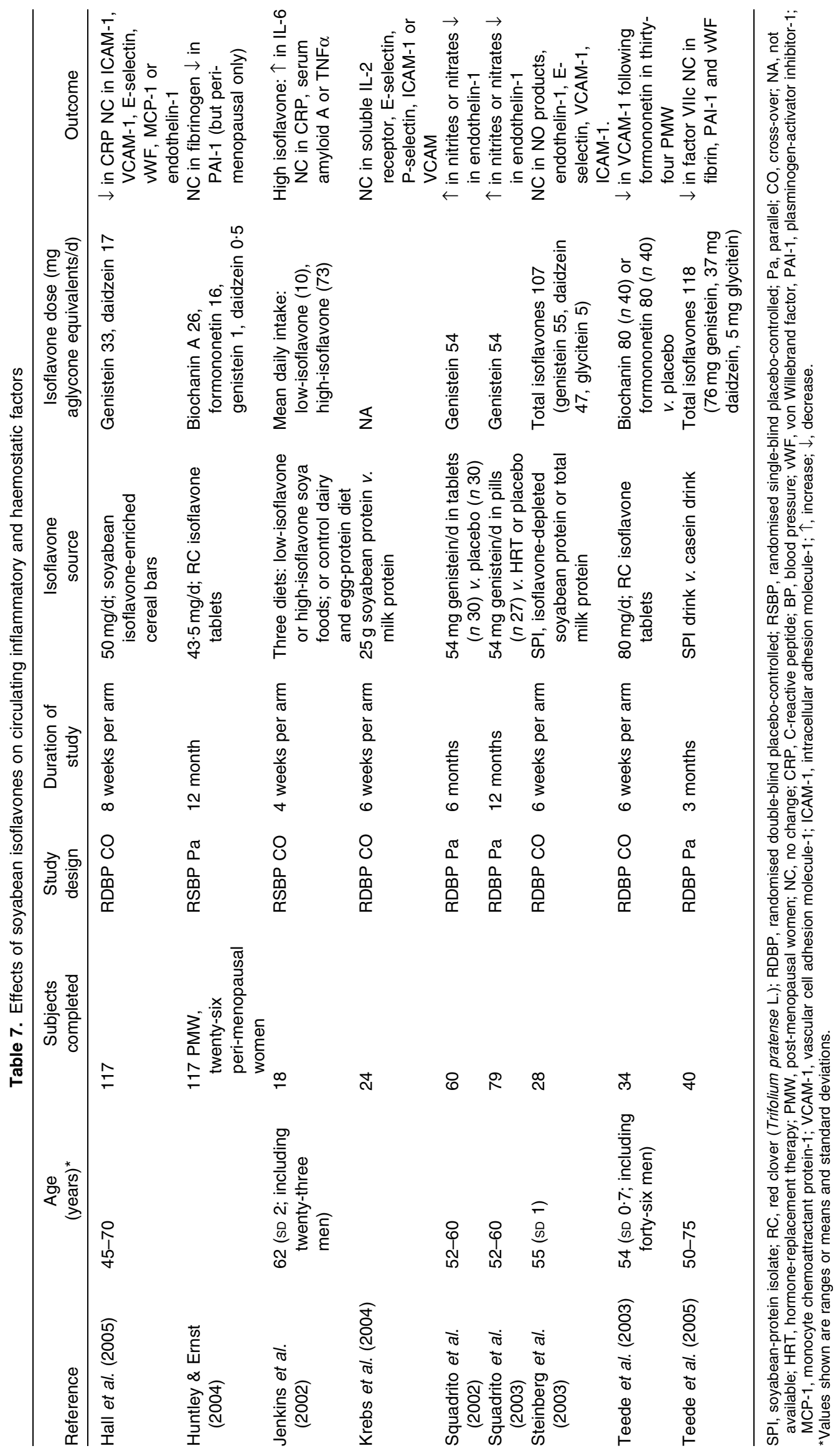


A. Cassidy et al.

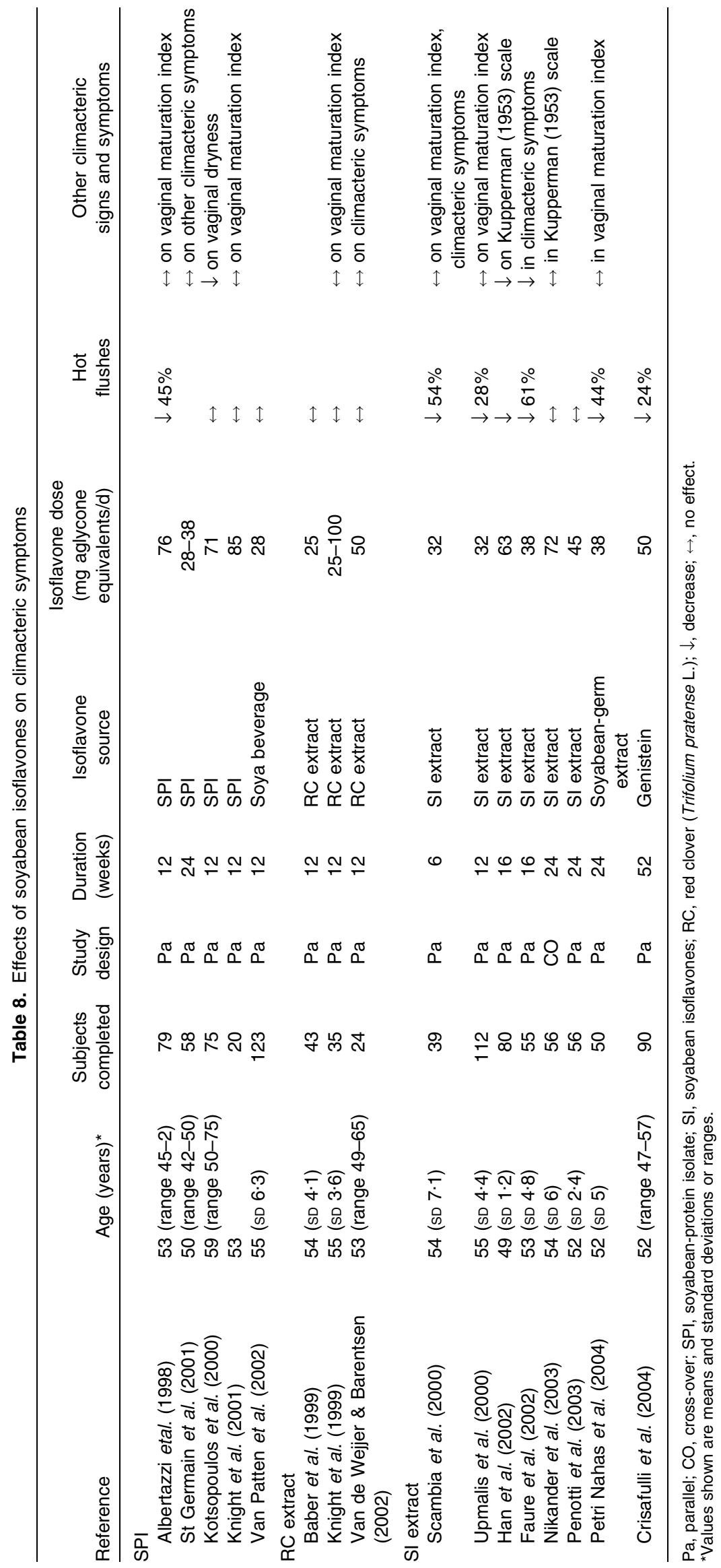


only two of the studies have observed a difference in the occurrence of other climacteric symptoms (Han et al. 2002; Petri Nahas et al. 2004). No change in vaginal dryness has been observed following intervention in any of the studies.

\section{Health effects: breast cancer}

Consensus statement on breast cancer: grade $C$ recommendation. On the basis of the available evidence the panel has concluded that there is some epidemiological evidence of an association between lifelong soyabean intake and reduced risk of breast cancer in premenopausal and post-menopausal women. Although to date three doubleblind RCT have been conducted, using mammographic density as a marker of breast cancer risk, none of these studies has examined effects in only post-menopausal women. Further studies are required to address the potential effect of soyabean on breast cancer and to address the current concerns of the potential risk-benefit profile of soyabean isoflavones for breast-cancer survivors.

Summary of data on breast cancer. Several observational epidemiological studies have examined the relationship between soyabean and breast cancer, relying on varying measures of soyabean intake, ranging from detailed analyses to crude estimates of the consumption of tofu. Eight case-control studies have examined the association between soyabean intake and breast cancer risk in Asian women in Singapore (Lee et al. 1991), Japan (Hirose et al. 1995; Yamamoto et al. 2003) and China (Yuan et al. 1995; Shu et al. 2001; Dai et al. 2002), and in AsianAmericans (Wu et al. 1996, 2002). Results from all these studies consistently suggest an inverse association for both premenopausal and post-menopausal breast cancer. In a meta-analysis (A Wolk, unpublished results) of these studies a significant $33 \%$ decreased risk of developing breast cancer has been observed for post-menopausal women (summary odds ratio 0.67 (95\% CI $0.48,0.93)$ ) when comparing the highest consumption with the lowest consumption in the respective study populations.

Fewer epidemiological studies have been conducted in Caucasian women, given their limited exposure to soyabean-based products. In one case-control study of premenopausal women from Germany (Linseisen et al. 2004) and one prospective study of post-menopausal women from The Netherlands (den Tonkelaar et al. 2001) summary estimates of risk are odds ratios of 0.61 (95\% CI, $0.43,0.86)$ and $0.83(95 \% \mathrm{CI}, 0.45,1.50)$ respectively. A recent Italian study has reported no association between isoflavones and breast cancer risk in premenopausal or post-menopausal women (Bosetti et al. 2005). The summary risk estimate indicates no association for postmenopausal women (summary odds ratio 0.96 (95\% CI 0.89, 1.04) based on the Dutch (den Tonkelaar et al. 2001) and Italian (Bosetti et al. 2005) studies). The summary risk estimate from the meta-analysis of two prospective studies of total breast cancer (premenopausal and post-menopausal women combined) among women from UK (Grace et al. 2004) and The Netherlands (Keinan-Boker et al. 2004) as well as a case-control study from Australia (Ingram et al. $1997)$ is an odds ratio of $0.96(95 \%$ CI, $0 \cdot 71,1 \cdot 29)$.
To date two studies, one based in China (Shu et al. 2001) and the other in the USA (Wu et al. 2002), have assessed the impact of adolescent dietary exposure in Asian women on breast cancer risk. Both studies have found a strong significant inverse association between dietary soyabean and post-menopausal breast cancer risk, with odds ratios of $0.49(95 \%$ CI $0.33,0.74)$ and 0.41 $(P=0.007$ for trend).

Two prospective nested case-control studies of prediagnostic urine in Caucasian women have shown conflicting results; a non-significant inverse association between excreted genistein and breast cancer in Dutch women (den Tonkelaar et al. 2001), and a positive association between excreted equol and breast cancer risk (odds ratio $1.34(95 \%$ CI 1.06, 1.70)) in English women (Grace et al. 2004). Case-control studies analysing urine collected after breast-cancer diagnosis have shown significant inverse associations; one for the metabolite equol (Ingram et al. 1997) and the other (in Asian women) in relation to total isoflavone excretion (Dai et al. 2002; odds ratios $0 \cdot 27(95 \% \mathrm{CI} 0 \cdot 1,0 \cdot 69)$ and $0 \cdot 46(95 \% \mathrm{CI} 0 \cdot 22,0 \cdot 95)$ respectively).

Two cross-sectional studies (Maskarinec \& Meng, 2001; Jakes et al. 2002) have looked specifically at soyabean intake and its association with breast tissue density. Maskarinec \& Meng (2001) have reported a higher density with higher soyabean intake and a non-significant reduction in dense area, while Jakes et al. (2002) have shown that higher soyabean intake is associated with lower risk mammographic patterns (odds ratio 0.44 (95\% CI $0 \cdot 18$, $0 \cdot 96)$.

To date three double-blind RCT have been conducted, two in premenopausal women (Maskarinec et al. 2003, 2004) and one with combined menopausal status (Atkinson et al. 2004b). No significant differences in mammographic characteristics that could be attributed to the soyabean intervention were observed. However, it is possible that the association between soyabean intake and breast density is different in post-menopausal women, among those women with a strong family history of the disease or in women with polymorphisms in genes that encode oestrogenmetabolising enzymes.

\section{Health effects: colon cancer}

Consensus statement on colon cancer: grade $C$ recommendation. The inconsistent results obtained by epidemiological studies provide no general support for the hypothesis that frequent ingestion of soyabean reduces the risk of colo-rectal cancer.

Summary of the data on colon cancer. Although the incidence of colo-rectal cancer is markedly lower in many Asian countries compared with Western populations, there is limited support from epidemiological studies for a potential protective role for soyabean and its isoflavones. Numerous epidemiological studies, predominantly using a case-control design, have examined the relationship between intake of different soyabean foods and colo-rectal cancer risk, but the data are contradictory (Haenszel et al. 1973; Watanabe et al. 1984; Tajima \& Tominaga, 1985; Hirayama, 1990; Hu et al. 1991; Hoshiyama et al. 1993; 
Le Marchand et al. 1997; Nishi et al. 1997; Seow et al. 2002).

In relation to colonic adenoma development two studies have examined the effect of the consumption of soyabean food on polyp growth (Kono et al. 1993; Witte et al. 1996). Although the findings from both studies are suggestive of an inverse relationship between the intake of miso soup (Kono et al. 1993) or tofu (Witte et al. 1996) and the development of colo-rectal adenomas, the relationship was not found to be significant.

\section{Health effects: cognitive function}

Consensus statement on cognitive function: grade $B$ recommendation. As there are few available studies, it is not possible to draw a conclusion on the effect of soyabean products or isoflavones on cognitive function in postmenopausal women.

Summary of the data on cognitive function. To date, three studies (Kritz-Silverstein et al. 2003; Howes et al. 2004; Kreijkamp-Kaspers et al. 2004) have examined the potential effects of phyto-oestrogens on cognitive function in post-menopausal women (Table 9). The study duration ranged from 6 to 12 months and the dose of isoflavones fed daily ranged from 32 to $69 \mathrm{mg}$ aglycone equivalents. The study with red clover (Kreijkamp-Kaspers et al. 2004) and the study with SPI (Howes et al. 2004) do not show any improvement in a range of cognitive tests such as verbal memory, digit span (a measure of short-term memory) and verbal fluency. The findings of the study performed with soyabean isoflavone extracts suggest an improvement in the category fluency (Kritz-Silverstein et al. 2003).

\section{Health effects: diabetes}

Consensus statement on the effect on diabetes: grade $C$ recommendation. There are limited studies that have specifically focused on diabetic women, but the available evidence suggests that there may be an effect of soyabean on diabetes. However, more studies of longer duration are needed to confirm this finding and to determine what active components may be causing the changes.

Summary of data on diabetes. The prevalence of diabetes is reaching epidemic proportions and is increasing in parallel with obesity. Cardiovascular mortality is up to five times higher in women with diabetes compared with those without diabetes, and the cardiovascular mortality rate is increasing in diabetic women (Hu et al. 2001; Collins et al. 2003; Bibbins-Domingo et al. 2004). Women who develop diabetes lose their cardiovascular protection from oestrogen, and post-menopausal oestrogen loss may contribute to a high risk of accelerated CVD.

Ten studies have examined the effect of phyto-oestrogens on post-menopausal diabetes. Of these studies only four (Hermansen et al. 2001; Jayagopal et al. 2002; Howes et al. 2003; Li et al. 2005) met the inclusion criteria of being focused on glycaemic control, but each study used different variables and they are therefore difficult to compare (Table 10). In addition, two studies used a mixed population of men and women (Hermansen et al. 2001; Li et al. 2005), whilst only two studies have focused on 
Phytochemicals

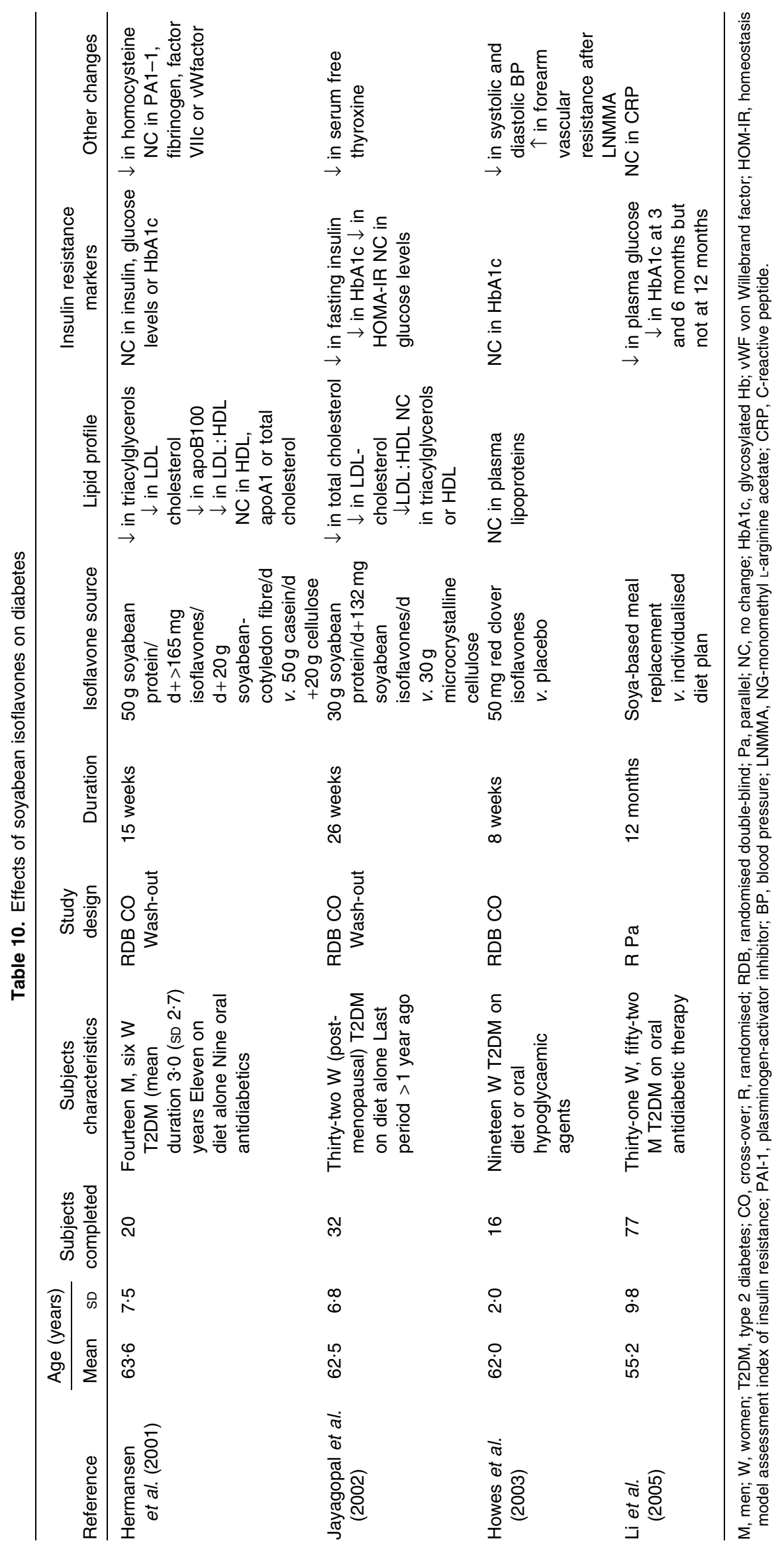


post-menopausal women alone (Jayagopal et al. 2002; Howes et al. 2003), and these latter two studies used markedly different isoflavone preparations. Hermansen et al. (2001), using $50 \mathrm{~g}$ soyabean protein plus $160 \mathrm{mg}$ isoflavone, have shown no change in glycaemic indices, whilst Howes et al. (2003) have shown no change in overall glycaemic control using $50 \mathrm{mg}$ red-clover isoflavone alone. Conversely, Jayagopal et al. (2002), using $30 \mathrm{~g}$ soyabean protein plus $132 \mathrm{mg}$ isoflavone, have shown a reduction in fasting insulin, glycosylated $\mathrm{Hb}$ and insulin resistance. Li et al. (2005), using a soyabean-based meal replacement, have shown a reduction in plasma glucose and glycosylated $\mathrm{Hb}$ at 3 and 6 months, an effect that is lost at 12 months. These studies suggest that a combination of soyabean protein and isoflavones could have a positive effect on diabetes control, although isoflavones alone may not be effective and not all studies are positive. It is unclear which component(s) is active, and indeed it may be the soluble fibre alone that is beneficial (Chandalia et al. 2000).

\section{Summary and conclusions}

The panel has concluded that because of the limited number of appropriately-designed studies and differences in methodological approaches there is no conclusive evidence on the different health aspects. However, the revision and weighing of the available evidence has led the panel to provide the following conclusions and recommendations, each one with its associated grading:

1. there is a suggestion but no conclusive evidence that isoflavones from the sources studied so far have a beneficial effect on bone health: grade A;

2. the consumption of whole-soyabean foods and SPI has beneficial effects on lipid markers of cardiovascular risk in healthy post-menopausal women. The consumption of isolated isoflavones does not affect blood lipid levels or blood pressure, although it may improve endothelial function: grade A;

3. for menopausal symptoms, there is currently limited evidence that SPI, soyabean foods or red-clover extract are effective but soyabean-isoflavone extracts may be effective in reducing hot flushes: grade A;

4. there is some epidemiological evidence of an association between lifelong soyabean intake and reduced risk of breast cancer in premenopausal and post-menopausal women. Although to date three double-blind RCT have been conducted, using mammographic density as a marker of breast cancer risk, none of these studies has examined effects in only post-menopausal women: grade C;

5. based on available evidence the consumption of soyabean does not lead to reduced risk of colo-rectal cancer: grade $\mathrm{C}$;

6. based on available evidence soyabean products or isoflavones do not have an effect on cognitive function in post-menopausal women: grade B;

7. based on available evidence soyabean consumption may reduce the risk of diabetes: grade $\mathrm{C}$.

In conclusion, the use of soyabean products and soyabean isoflavones may be beneficial in post-menopausal women for bone, cardiovascular risk and hot flushes. However, the benefits are subtle and do not appear in all individuals. There are too few RCT studies to reach conclusions on the effects of isoflavones on breast cancer, colon cancer, diabetes or cognitive function.

\section{Recommendations for research}

Understanding the bioavailability of isoflavones in a given foodstuff will be important in the interpretation of the results of studies of clinical effects. Most importantly, it is essential to measure accurately the amount and form of isoflavones at the point of consumption during the study, and to check this information at regular intervals. Together, factors such as glycoside $v$. aglycone, food source, the 'equol-producer' state of the volunteers and the influence of other foods eaten during the study can determine whether a significant biological or clinical effect is observed, or not.

Adequately-powered human intervention studies that can definitely establish the benefits of either encapsulated isoflavones or isoflavone-fortified foods on clinical outcomes such as the incidence of heart disease and bone fractures are needed.

Appropriately-designed studies are required to examine the effects of soyabean and soyabean isoflavones on breast cancer, diabetes, colo-rectal cancer and cognitive function.

\section{Acknowledgements}

The EU (QLKII-CT-2002-02453) are thanked for supporting the Phytohealth Network of Excellence. This paper is written on behalf of the Phytohealth consortium. Special thanks go to Eva Grammatikaki and Suzanna Gonzalez for their contribution to this consensus paper. This study does not necessarily reflect the views of the Commission and in no way anticipates the Commissions's future policy in this area.

\section{References}

Agency for Health Care Policy and Research (1992) Clinical Practice Guideline for Acute Pain Management: Operative or Medical Procedures and Trauma. AHCPR Publication no. 92-0032. 1st ed. Rockville, MD: Public Health Service, US Department of Health and Human Services.

Albertazzi P, Pansini F, Bonaccorsi G, Zanotti L, Forini E \& De Aloysio D (1998) The effect of dietary soy supplementation on hot flushes. Obstetrics and Gynecology 91, 6-11.

Anderson JW, Johnstone BM \& Cook-Newell ME (1995) Metaanalysis of the effects of soy protein intake on serum lipids. New England Journal of Medicine 333, 276-282.

Atkinson C, Oosthuizen W, Scollen S, Loktionov A, Day NE \& Bingham SA (2004a) Modest protective effects of isoflavones from a red clover-derived dietary supplement on cardiovascular disease risk factors in perimenopausal women, and evidence of an interaction with ApoE genotype in 49-65 year-old women. Journal of Nutrition 134, 1759-1764.

Atkinson C, Warren RM, Sala E, Dowsett M, Dunning AM, Healey CS, Runswick S, Day NE \& Bingham SA (2004b) Red-clover-derived isoflavones and mammographic breast 
density: a double-blind, randomized, placebo-controlled trial. Breast Cancer Research 6, R170-R179.

Baber RJ, Templeman C, Morton T, Kelly GE \& West L (1999) Randomized placebo-controlled trial of an isoflavone supplement and menopausal symptoms in women. Climacteric 2, 85-92.

Bibbins-Domingo K, Lin F, Vittinghoff E, Barrett-Connor E, Hulley SB, Grady D \& Shlipak MG (2004) Predictors of heart failure among women with coronary disease. Circulation 110, $1424-1430$.

Blum A, Lang N, Peleg A, Vigder F, Israeli P, Gumanovsky M, Lupovitz S, Elgazi A \& Ben-Ami M (2003a) Effects of oral soy protein on markers of inflammation in postmenopausal women with mild hypercholesterolemia. American Heart Journal 145, e7.

Blum A, Lang N, Vigder F, Israeli P, Gumanovsky M, Lupovitz S, Elgazi A, Peleg A \& Ben-Ami M (2003b) Effects of soy protein on endothelium-dependent vasodilatation and lipid profile in postmenopausal women with mild hypercholesterolemia. Clinical and Investigative Medicine 26, 20-26.

Bosetti C, Spertini L, Parpinel M, Gnagnarella P, Lagiou P, Negri E et al. (2005) Flavonoids and breast cancer risk in Italy. Cancer Epidemiology, Biomarkers \& Prevention 14, 805-808.

Campbell MJ, Woodside JV, Honour JW, Morton MS \& Leathem AJ (2004) Effect of red clover-derived isoflavone supplementation on insulin-like growth factor, lipid and antioxidant status in healthy female volunteers: a pilot study. European Journal of Clinical Nutrition 58, 173-179.

Chandalia M, Garg A, Lutjohann D, von Bergmann K, Grundy SM \& Brinkley LJ (2000) Beneficial effects of high dietary fiber intake in patients with type 2 diabetes mellitus. New England Journal of Medicine 342, 1392-1398.

Chen YM, Ho SC, Lam SS, Ho SS \& Woo JL (2003) Soy isoflavones have a favorable effect on bone loss in Chinese postmenopausal women with lower bone mass: a double-blind, randomized, controlled trial. Journal of Clinical Endocrinology and Metabolism 88, 4740-4747.

Clifton-Bligh PB, Baber RJ, Fulcher GR, Nery ML \& Moreton T (2001) The effect of isoflavones extracted from red clover (Rimostil) on lipid and bone metabolism. Menopause $\mathbf{8}$, 259-265.

Collins R, Armitage J, Parish S, Sleigh P \& Peto R (2003) MRC/ BHF Heart Protection Study of cholesterol-lowering with simvastatin in 5963 people with diabetes: a randomised placebo-controlled trial. Lancet 361, 2005-2016.

Crisafulli A, Marini H, Bitto A, Altavilla D, Squadrito G, Romeo A et al. (2004) Effects of genistein on hot flushes in early postmenopausal women: a randomized, double-blind EPT- and placebo-controlled study. Menopause 11, 400-404.

Cuevas AM, Irribarra VL, Castillo OA, Yanez MD \& Germain AM (2003) Isolated soy protein improves endothelial function in postmenopausal hypercholesterolemic women. European Journal of Clinical Nutrition 57, 889-894.

Dai Q, Franke AA, Jin F, Shu XO, Hebert JR, Custer LJ, Cheng J, Gao YT \& Zheng W (2002) Urinary excretion of phytoestrogens and risk of breast cancer among Chinese women in Shanghai. Cancer Epidemiology, Biomarkers \& Prevention 11, 815-821.

Day AJ, Canada FJ, Diaz JC, Kroon PA, McLauchlan R, Faulds CB, Plumb GW, Morgan MR \& Williamson G (2000) Dietary flavonoid and isoflavone glycosides are hydrolysed by the lactase site of lactase phlorizin hydrolase. FEBS Letters $\mathbf{4 6 8}$, 166-170.

den Tonkelaar I, Keinan-Boker L, Veer PV, Arts CJ, Adlercreutz H, Thijssen JH \& Peeters PH (2001) Urinary phytoestrogens and postmenopausal breast cancer risk. Cancer Epidemiology, Biomarkers \& Prevention 10, 223-228.
Desroches S, Mauger JF, Ausman LM, Lichtenstein AH \& Lamarche B (2004) Soy protein favorably affects LDL size independently of isoflavones in hypercholesterolemic men and women. Journal of Nutrition 134, 574-579.

Dewell A, Hollenbeck CB \& Bruce B (2002) The effects of soy-derived phytoestrogens on serum lipids and lipoproteins in moderately hypercholesterolemic postmenopausal women. Journal of Clinical Endocrinology and Metabolism 87, $118-121$.

Eisen B, Ungar Y \& Shimoni E (2003) Stability of isoflavones in soy milk stored at elevated and ambient temperatures. Journal of Agricultural and Food Chemistry 51, 2212-2215.

Faughnan MS, Hawdon A, Ah-Singh E, Brown J, Millward DJ \& Cassidy A (2004) Urinary isoflavone kinetics: the effect of age, gender, food matrix and chemical composition. British Journal of Nutrition 91, 567-574.

Faure ED, Chantre P \& Mares P (2002) Effects of a standardized soy extract on hot flushes: a multicenter, double-blind, randomized, placebo-controlled study. Menopause 9, 329-334.

Gallagher JC, Satpathy R, Rafferty K \& Haynatzka V (2004) The effect of soy protein isolate on bone metabolism. Menopause 11, 290-298.

Gardner CD, Newell KA, Cherin R \& Haskell WL (2001) The effect of soy protein with or without isoflavones relative to milk protein on plasma lipids in hypercholesterolemic postmenopausal women. American Journal of Clinical Nutrition 73, 728-735.

Grace PB, Taylor JI, Low YL, Luben RN, Mulligan AA, Botting NP et al. (2004) Phytoestrogen concentrations in serum and spot urine as biomarkers for dietary phytoestrogen intake and their relation to breast cancer risk in European prospective investigation of cancer and nutritionnorfolk. Cancer Epidemiology, Biomarkers \& Prevention 13, 698-708.

Greene JG (1998) Constructing a standard climacteric scale. Maturitas 29, 25-31.

Haenszel W, Berg JW, Segi M, Kurihara M \& Locke FB (1973) Large-bowel cancer in Hawaiian Japanese. Journal of the National Cancer Institute 51, 1765-1779.

Hall WL, Vafeiadou K, Minihane AM, Williams CM \& Rimbach GH (2004) Isoflavones and coronary heart disease. In Functional Foods, Cardiovascular Disease and Diabetes, pp. 187-214 [A Arnoldi, editor]. Cambridge: Woodhead Publishing Ltd.

Hall WL, Vafeiadou K, Hallund J, Bugel S, Koebnick C, Reimann M et al. (2005) Soy isoflavone enriched foods and inflammatory biomarkers of cardiovascular risk in postmenopausal women: interactions with genotype and equol production. American Journal of Clinical Nutrition (In the Press).

Han KK, Soares JM Jr, Haidar MA, de Lima GR \& Baracat EC (2002) Benefits of soy isoflavone therapeutic regimen on menopausal symptoms. Obstetrics and Gynecology 99, 389-394.

Harbour R \& Miller J (2001) A new system for grading recommendations in evidence based guidelines. British Medical Journal 323, 334-336.

Hermansen K, Sondergaard M, Hoie L, Carstensen M \& Brock B (2001) Beneficial effects of a soy-based dietary supplement on lipid levels and cardiovascular risk markers in type 2 diabetic subjects. Diabetes Care 24, 228-233.

Hirayama T (1990) Life-style and Mortality. A Large-scale Census-based Cohort Study in Japan. Basel, Switzerland: Karger.

Hirose K, Tajima K, Hamajima N, Inoue M, Takezaki T, Kuroishi T, Yoshida M \& Tokudome S (1995) A large-scale, hospital-based case-control study of risk factors of breast 
cancer according to menopausal status. Japanese Journal of Cancer Research 86, 146-154.

Hodgson JM, Puddey IB, Beilin LJ, Mori TA, Burke V, Croft KD \& Rogers PB (1999a) Effects of isoflavonoids on blood pressure in subjects with high-normal ambulatory blood pressure levels: a randomized controlled trial. American Journal of Hypertension 12, 47-53.

Hodgson JM, Puddey IB, Beilin LJ, Mori TA \& Croft KD (1998) Supplementation with isoflavonoid phytoestrogens does not alter serum lipid concentrations: a randomized controlled trial in humans. Journal of Nutrition 128, 728-732.

Hodgson JM, Puddey IB, Croft KD, Mori TA, Rivera J \& Beilin LJ (1999b) Isoflavonoids do not inhibit in vivo lipid peroxidation in subjects with high-normal blood pressure. Atherosclerosis 145, 167-172.

Hoshiyama Y, Sekine T \& Sasaba T (1993) A case-control study of colorectal cancer and its relation to diet, cigarettes, and alcohol consumption in Saitama Prefecture, Japan. Tohoku Journal of Experimental Medicine 171, 153-165.

Howes JB, Bray K, Lorenz L, Smerdely P \& Howes LG (2004) The effects of dietary supplementation with isoflavones from red clover on cognitive function in postmenopausal women. Climacteric 7, 70-77.

Howes JB, Sullivan D, Lai N, Nestel P, Pomeroy S, West L, Eden JA \& Howes LG (2000) The effects of dietary supplementation with isoflavones from red clover on the lipoprotein profiles of post menopausal women with mild to moderate hypercholesterolaemia. Atherosclerosis 152, 143-147.

Howes JB, Tran D, Brillante D \& Howes LG (2003) Effects of dietary supplementation with isoflavones from red clover on ambulatory blood pressure and endothelial function in postmenopausal type 2 diabetes. Diabetes Obesity \& Metabolism 5, 325-332.

Hu FB, Manson JE, Stampfer MJ, Colditz G, Liu S, Solomon CG \& Willett WC (2001) Diet, lifestyle, and the risk of type 2 diabetes mellitus in women. New England Journal of Medicine 345, 790-797.

Hu JF, Liu YY, Yu YK, Zhao TZ, Liu SD \& Wang QQ (1991) Diet and cancer of the colon and rectum: a case-control study in China. International Journal of Epidemiology 20, 362-367.

Huntley AL \& Ernst E (2003) A systematic review of herbal medicinal products for the treatment of menopausal symptoms. Menopause 10, 465-476.

Huntley AL \& Ernst E (2004) Soy for the treatment of perimenopausal symptoms - a systematic review. Maturitas 47, 1-9.

Ingram D, Sanders K, Kolybaba M \& Lopez D (1997) Casecontrol study of phyto-oestrogens and breast cancer. Lancet 350, 990-994

Izumi T, Piskula MK, Osawa S, Obata A, Tobe K, Saito M, Kataoka S, Kubota Y \& Kikuchi M (2000) Soy isoflavone aglycones are absorbed faster and in higher amounts than their glucosides in humans. Journal of Nutrition 130, 1695-1699.

Jadad AR, Moore RA, Carroll D, Jenkinson C, Reynolds DJ, Gavaghan DJ \& McQuay HJ (1996) Assessing the quality of reports of randomized clinical trials: is blinding necessary? Controlled Clinical Trials 17, 1-12.

Jakes RW, Duffy SW, Ng FC, Gao F, Ng EH, Seow A, Lee HP \& Yu MC (2002) Mammographic parenchymal patterns and selfreported soy intake in Singapore Chinese women. Cancer Epidemiology, Biomarkers \& Prevention 11, 608-613.

Jayagopal V, Albertazzi P, Kilpatrick ES, Howarth EM, Jennings PE, Hepburn DA \& Atkin SL (2002) Beneficial effects of soy phytoestrogen intake in postmenopausal women with type 2 diabetes. Diabetes Care 25, 1709-1714.

Jenkins DJ, Kendall CW, Connelly PW, Jackson CJ, Parker T, Faulkner D \& Vidgen E (2002) Effects of high- and lowisoflavone (phytoestrogen) soy foods on inflammatory biomarkers and proinflammatory cytokines in middle-aged men and women. Metabolism 51, 919-924.

Keinan-Boker L, van Der Schouw YT, Grobbee DE \& Peeters PH (2004) Dietary phytoestrogens and breast cancer risk. American Journal of Clinical Nutrition 79, 282-288.

King RA \& Bursill DB (1998) Plasma and urinary kinetics of the isoflavones daidzein and genistein after a single soy meal in humans. American Journal of Clinical Nutrition 67, 867-872.

Knight DC, Howes JB \& Eden JA (1999) The effect of Promensil, an isoflavone extract, on menopausal symptoms. Climacteric 2, 79-84.

Knight DC, Howes JB, Eden JA \& Howes LG (2001) Effects on menopausal symptoms and acceptability of isoflavonescontaining soy powder dietary supplementation. Climacteric $\mathbf{4}$, $13-18$.

Kono S, Imanishi K, Shinchi K \& Yanai F (1993) Relationship of diet to small and large adenomas of the sigmoid colon. Japanese Journal of Cancer Research 84, 13-19.

Kotsopoulos D, Dalais FS, Liang YL, McGrath BP \& Teede HJ (2000) The effects of soy protein containing phytoestrogens on menopausal symptoms in postmenopausal women. Climacteric 3, 161-167.

Krebs EE, Ensrud KE, MacDonald R \& Wilt TJ (2004) Phytoestrogens for treatment of menopausal symptoms: a systematic review. Obstetrics and Gynecology 104, 824-836.

Kreijkamp-Kaspers S, Kok L, Grobbee DE, de Haan EH, Aleman A, Lampe JW \& van der Schouw YT (2004) Effect of soy protein containing isoflavones on cognitive function, bone mineral density, and plasma lipids in postmenopausal women: a randomized controlled trial. Journal of the American Medical Association 292, 65-74.

Kritz-Silverstein D, Von Muhlen D, Barrett-Connor E \& Bressel MA (2003) Isoflavones and cognitive function in older women: the SOy and Postmenopausal Health In Aging (SOPHIA) Study. Menopause 10, 196-202.

Kupperman HS, Blatt M, Wiesbader H \& Filler W (1953) Comparative clinical evaluation of estrogenic preparations by the menopausal and amenorrheal indices. Journal of Clinical Endocrinology and Metabolism 13, 688-703.

Lampe JW, Karr SC, Hutchins AM \& Slavin JL (1998) Urinary equol excretion with a soy challenge: influence of habitual diet. Proceedings of the Society for Experimental Biology and Medicine 217, 335-339.

Le Marchand L, Hankin JH, Wilkens LR, Kolonel LN, Englyst HN \& Lyu LC (1997) Dietary fiber and colorectal cancer risk. Epidemiology 8, 658-665.

Lee HP, Gourley L, Duffy SW, Esteve J, Lee J \& Day NE (1991) Dietary effects on breast-cancer risk in Singapore. Lancet 337, $1197-1200$

Lee SJ, Ahn JK, Kim SH, Kim JT, Han SJ, Jung MY \& Chung IM (2003) Variation in isoflavone of soybean cultivars with location and storage duration. Journal of Agricultural and Food Chemistry 51, 3382-3389.

Li Z, Hong K, Saltsman P, DeShields S, Bellman M, Thames G, Liu Y, Wang HJ, Elashoff R \& Heber D (2005) Long-term efficacy of soy-based meal replacements vs an individualized diet plan in obese type II DM patients: relative effects on weight loss, metabolic parameters, and C-reactive protein European Journal of Clinical Nutrition 59, 411-418.

Lichtenstein AH, Jalbert SM, Adlercreutz H, Goldin BR, Rasmussen H, Schaefer EJ \& Ausman LM (2002) Lipoprotein response to diets high in soy or animal protein with and without isoflavones in moderately hypercholesterolemic subjects. Arteriosclerosis, Thrombosis, and Vascular Biology 22, 1852-1858

Linseisen J, Piller R, Hermann S \& Chang-Claude J (2004) Dietary phytoestrogen intake and premenopausal breast cancer 
risk in a German case-control study. International Journal of Cancer 110, 284-290.

Lissin LW, Oka R, Lakshmi S \& Cooke JP (2004) Isoflavones improve vascular reactivity in post-menopausal women with hypercholesterolemia. Vascular Medicine 9, 26-30.

Lock M (1993) Encounters with Ageing. Mythology of Menopause in Japan and North America. Oakland, CA: University of California Press.

Lu LJ \& Anderson KE (1998) Sex and long-term soy diets affect the metabolism and excretion of soy isoflavones in humans. American Journal of Clinical Nutrition 68, 1500S-1504S.

Mackey R, Ekangaki A \& Eden JA (2000) The effects of soy protein in women and men with elevated plasma lipids. Biofactors 12, 251-257.

Mahungu SM, Diaz-Mercado S, Li J, Schwenk M, Singletary K \& Faller J (1999) Stability of isoflavones during extrusion processing of corn/soy mixture. Journal of Agricultural and Food Chemistry 47, 279-284.

Maskarinec G, Franke AA, Williams AE, Hebshi S, Oshiro C, Murphy S \& Stanczyk FZ (2004) Effects of a 2-year randomized soy intervention on sex hormone levels in premenopausal women. Cancer Epidemiology, Biomarkers \& Prevention 13, 1736-1744.

Maskarinec G \& Meng L (2001) An investigation of soy intake and mammographic characteristics in Hawaii. Breast Cancer Research 3, 134-141.

Maskarinec G, Williams AE \& Carlin L (2003) Mammographic densities in a one-year isoflavone intervention. European Journal of Cancer Prevention 12, 165-169.

Morabito N, Crisafulli A, Vergara C, Gaudio A, Lasco A, Frisina $\mathrm{N}$ et al. (2002) Effects of genistein and hormone-replacement therapy on bone loss in early postmenopausal women: a randomized double-blind placebo-controlled study. Journal of Bone and Mineral Research 17, 1904-1912.

Nestel PJ, Pomeroy S, Kay S, Komesaroff P, Behrsing J, Cameron JD \& West L (1999) Isoflavones from red clover improve systemic arterial compliance but not plasma lipids in menopausal women. Journal of Clinical Endocrinology and Metabolism 84, 895-898.

Nestel PJ, Yamashita T, Sasahara T, Pomeroy S, Dart A, Komesaroff P, Owen A \& Abbey M (1997) Soy isoflavones improve systemic arterial compliance but not plasma lipids in menopausal and perimenopausal women. Arteriosclerosis, Thrombosis, and Vascular Biology 17, 3392-3398.

Nikander E, Kilkkinen A, Metsa-Heikkila M, Adlercreutz H, Pietinen P, Tiitinen A \& Ylikorkala O (2003) A randomized placebo-controlled crossover trial with phytoestrogens in treatment of menopause in breast cancer patients. Obstetrics and Gynecology 101, 1213-1220.

Nishi M, Yoshida K, Hirata K \& Miyake H (1997) Eating habits and colorectal cancer. Oncology Reports 4, 995-998.

Penotti M, Fabio E, Modena AB, Rinaldi M, Omodei U \& Vigano P (2003) Effect of soy-derived isoflavones on hot flushes, endometrial thickness, and the pulsatility index of the uterine and cerebral arteries. Fertility and Sterility 79, $1112-1117$

Petri Nahas E, Nahas Neto J, De Luca L, Traiman P, Pontes A \& Dalben I (2004) Benefits of soy germ isoflavones in postmenopausal women with contraindication for conventional hormone replacement therapy. Maturitas $\mathbf{4 8}$, 372-380.

Potter SM, Baum JA, Teng HY, Stillman RJ, Shay NF \& Erdman JW (1998) Soy protein and isoflavones: their effects on blood lipids and bone density in postmenopausal women. American Journal of Clinical Nutrition 68, 1375S-1379S.

Puska P, Korpelainen V, Hoie LH, Skovlund E, Lahti T \& Smerud KT (2002) Soy in hypercholesterolaemia: a double-blind, placebo-controlled trial. European Journal of Clinical Nutrition 56, 352-357.

Rowland I, Wiseman H, Sanders T, Adlercreutz H \& Bowey E (1999) Metabolism of oestrogens and phytoestrogens: role of the gut microflora. Biochemical Society Transactions 27, 304-308.

Scambia G, Mango D, Signorile PG, Angeli RA, Palena C, Gallo D, Bombardelli E, Morazzoni P, Riva A \& Mancuso S (2000) Clinical effects of a standardized soy extract in postmenopausal women: A pilot study. Menopause 7, 105-111.

Seow A, Quah SR, Nyam D, Straughan PT, Chua T \& Aw TC (2002) Food groups and the risk of colorectal carcinoma in an Asian population. Cancer 95, 2390-2396.

Setchell KD (1998) Phytoestrogens: the biochemistry, physiology, and implications for human health of soy isoflavones. American Journal of Clinical Nutrition 68, 1333S-1346S.

Setchell KD, Borriello SP, Hulme P, Kirk DN \& Axelson M (1984) Nonsteroidal estrogens of dietary origin: possible roles in hormone-dependent disease. American Journal of Clinical Nutrition 40, 569-578.

Setchell KD, Brown NM, Desai P, Zimmer-Nechemias L, Wolfe BE, Brashear WT, Kirschner AS, Cassidy A \& Heubi JE (2001) Bioavailability of pure isoflavones in healthy humans and analysis of commercial soy isoflavone supplements. Journal of Nutrition 131, 1362S-1375S.

Setchell KD, Brown NM, Desai PB, Zimmer-Nechimias L, Wolfe B, Jakate AS, Creutzinger V \& Heubi JE (2003a) Bioavailability, disposition, and dose-response effects of soy isoflavones when consumed by healthy women at physiologically typical dietary intakes. Journal of Nutrition $\mathbf{1 3 3}$, $1027-1035$.

Setchell KD, Brown NM \& Lydeking-Olsen E (2002a) The clinical importance of the metabolite equol - a clue to the effectiveness of soy and its isoflavones. Journal of Nutrition 132, 3577-3584.

Setchell KD, Brown NM, Zimmer-Nechemias L, Brashear WT, Wolfe BE, Kirschner AS \& Heubi JE (2002b) Evidence for lack of absorption of soy isoflavine glycosides in humans, supporting the crucial role of intestinal metabolism for bioavailability. American Journal of Clinical Nutrition $\mathbf{7 6}$, 447-453.

Setchell KD, Faughnan MS, Avades T, Zimmer-Nechemias L, Brown NM, Wolfe BE, Brashear WT, Desai P, Oldfield MF, Botting NP \& Cassidy A (2003b) Comparing the pharmacokinetics of daidzein and genistein with the use of 13C-labeled tracers in premenopausal women. American Journal of Clinical Nutrition 77, 411-419.

Setchell KD, Zimmer-Nechemias L, Cai J \& Heubi JE (1997) Exposure of infants to phyto-oestrogens from soy-based infant formula. Lancet 350, 23-27.

Shelnutt SR, Cimino CO, Wiggins PA, Ronis MJ \& Badger TM (2002) Pharmacokinetics of the glucuronide and sulfate conjugates of genistein and daidzein in men and women after consumption of a soy beverage. American Journal of Clinical Nutrition 76, 588-594.

Shu XO, Jin F, Dai Q, Wen W, Potter JD, Kushi LH, Ruan Z, Gao YT \& Zheng W (2001) Soyfood intake during adolescence and subsequent risk of breast cancer among Chinese women. Cancer Epidemiology, Biomarkers \& Prevention 10, 483-488.

Simons LA, von Konigsmark M, Simons J \& Celermajer DS (2000) Phytoestrogens do not influence lipoprotein levels or endothelial function in healthy, postmenopausal women. American Journal of Cardiology 85, 1297-1301.

Squadrito F, Altavilla D, Crisafulli A, Saitta A, Cucinotta D, Morabito N, D'Anna R, Corrado F, Ruggeri P, Frisina N \& Squadrito G (2003) Effect of genistein on endothelial function in postmenopausal women: a randomized, 
double-blind, controlled study. American Journal of Medicine 114, 470-476.

Squadrito F, Altavilla D, Morabito N, Crisafulli A, D'Anna R, Corrado F, Ruggeri P, Campo GM, Calapai G, Caputi AP \& Squadrito G (2002) The effect of the phytoestrogen genistein on plasma nitric oxide concentrations, endothelin-1 levels and endothelium dependent vasodilation in postmenopausal women. Atherosclerosis 163, 339-347.

St Germain A, Peterson CT, Robinson JG \& Alekel L (2001) Isoflavone-rich or isoflavone-poor soy protein does not reduce menopausal symptoms during 24 weeks of treatment. Menopause 8, 17-26.

Steinberg FM, Guthrie NL, Villablanca AC, Kumar K \& Murray MJ (2003) Soy protein with isoflavones has favorable effects on endothelial function that are independent of lipid and antioxidant effects in healthy postmenopausal women. American Journal of Clinical Nutrition 78, 123-130.

Tajima K \& Tominaga S (1985) Dietary habits and gastrointestinal cancers: a comparative case-control study of stomach and large intestinal cancers in Nagoya, Japan. Japanese Journal of Cancer Research 76, 705-716.

Teede HJ, Dalais FS, Kotsopoulos D, Liang YL, Davis S \& McGrath BP (2001) Dietary soy has both beneficial and potentially adverse cardiovascular effects: a placebo-controlled study in men and postmenopausal women. Journal of Clinical Endocrinology and Metabolism 86, 3053-3060.

Teede HJ, Dalais FS, Kotsopoulos D, McGrath BP, Malan E, Gan TE \& Peverill RE (2005) Dietary soy containing phytoestrogens does not activate the hemostatic system in postmenopausal women. Journal of Clinical Endocrinology and Metabolism 90, 1936-1941.

Teede HJ, McGrath BP, DeSilva L, Cehun M, Fassoulakis A \& Nestel PJ (2003) Isoflavones reduce arterial stiffness: a placebo-controlled study in men and postmenopausal women. Arteriosclerosis, Thrombosis, and Vascular Biology 23, 1066-1071.

Tew BY, Xu X, Wang HJ, Murphy PA \& Hendrich S (1996) A diet high in wheat fiber decreases the bioavailability of soybean isoflavones in a single meal fed to women. Journal of Nutrition 126, 871-877.

Turner R, Baron T, Wolffram S, Minihane AM, Cassidy A, Rimbach G \& Weinberg PD (2004) Effect of circulating forms of soy isoflavones on the oxidation of low density lipoprotein. Free Radical Research 38, 209-216.

Upmalis DH, Lobo R, Bradley L, Warren M, Cone FL \& Lamia CA (2000) Vasomotor symptom relief by soy isoflavone extract tablets in postmenopausal women: A multicenter, double-blind, randomized, placebo-controlled study. Menopause 7, 236-242.

van de Weijer PH \& Barentsen R (2002) Isoflavones from red clover (Promensil) significantly reduce menopausal hot flush symptoms compared with placebo. Maturitas $\mathbf{4 2}$, 187-193.

Van Patten CL, Olivotto IA, Chambers GK, Gelmon KA, Hislop TG, Templeton E, Wattie A \& Prior JC (2002) Effect of soy phytoestrogens on hot flashes in postmenopausal women with breast cancer: a randomized, controlled clinical trial. Journal of Clinical Oncology 20, 1449-1455.

Vigna GB, Pansini F, Bonaccorsi G, Albertazzi P, Donega P, Zanotti L, De Aloysio D, Mollica G \& Fellin R (2000) Plasma lipoproteins in soy-treated postmenopausal women: a doubleblind, placebo-controlled trial. Nutrition, Metabolism and Cardiovascular Diseases 10, 315-322.
Wangen KE, Duncan AM, Xu X \& Kurzer MS (2001) Soy isoflavones improve plasma lipids in normocholesterolemic and mildly hypercholesterolemic postmenopausal women. American Journal of Clinical Nutrition 73, 225-231.

Washburn S, Burke GL, Morgan T \& Anthony M (1999) Effect of soy protein supplementation on serum lipoproteins, blood pressure, and menopausal symptoms in perimenopausal women. Menopause 6, 7-13.

Watanabe S, Yamaguchi M, Sobue T, Takahashi T, Miura T, Arai Y, Mazur W, Wahala K \& Adlercreutz H (1998) Pharmacokinetics of soybean isoflavones in plasma, urine and feces of men after ingestion of $60 \mathrm{~g}$ baked soybean powder (kinako). Journal of Nutrition 128, 1710-1715.

Watanabe Y, Tada M, Kawamoto K, Uozumi G, Kajiwara Y, Hayashi K et al. (1984) A case-control study of cancer of the rectum and colon (in Japanese). Nippon Shokakibyo Gakkai Zasshi 81, 185-193.

Weggemans RM \& Trautwein EA (2003) Relation between soy-associated isoflavones and LDL and HDL cholesterol concentrations in humans: a meta-analysis. European Journal of Clinical Nutrition 57, 940-946.

Wilkinson AP, Gee JM, Dupont MS, Needs PW, Mellon FA, Williamson G \& Johnson IT (2003) Hydrolysis by lactase phlorizin hydrolase is the first step in the uptake of daidzein glucosides by rat small intestine in vitro. Xenobiotica 33, 255-264.

Witte JS, Longnecker MP, Bird CL, Lee ER, Frankl HD \& Haile RW (1996) Relation of vegetable, fruit, and grain consumption to colorectal adenomatous polyps. American Journal of Epidemiology 144, 1015-1025.

Wu AH, Wan P, Hankin J, Tseng CC, Yu MC \& Pike MC (2002) Adolescent and adult soy intake and risk of breast cancer in Asian-Americans. Carcinogenesis 23, 1491-1496.

Wu AH, Ziegler RG, Horn-Ross PL, Nomura AM, West DW, Kolonel LN, Rosenthal JF, Hoover RN \& Pike MC (1996) Tofu and risk of breast cancer in Asian-Americans. Cancer Epidemiology, Biomarkers \& Prevention 5, 901-906.

Xu X, Wang HJ, Murphy PA \& Hendrich S (2000) Neither background diet nor type of soy food affects short-term isoflavone bioavailability in women. Journal of Nutrition 130, 798-801.

Xu Z, Wu Q \& Godber JS (2002) Stabilities of daidzin, glycitin, genistin, and generation of derivatives during heating. Journal of Agricultural and Food Chemistry 50, 7402-7406.

Yamamoto S, Sobue T, Kobayashi M, Sasaki S \& Tsugane S (2003) Soy, isoflavones, and breast cancer risk in Japan. Journal of the National Cancer Institute 95, 906-913.

Yeung J \& Yu TF (2003) Effects of isoflavones (soy phytoestrogens) on serum lipids: a meta-analysis of randomized controlled trials. Nutrition Journal 2, 15.

Yuan JM, Wang QS, Ross RK, Henderson BE \& Yu MC (1995) Diet and breast cancer in Shanghai and Tianjin, China. British Journal of Cancer 71, 1353-1358.

Zhang Y, Hendrich S \& Murphy PA (2003) Glucuronides are the main isoflavone metabolites in women. Journal of Nutrition 133, 399-404.

Zheng W, Dai Q, Custer LJ, Shu XO, Wen WQ, Jin F \& Franke AA (1999) Urinary excretion of isoflavonoids and the risk of breast cancer. Cancer Epidemiology, Biomarkers \& Prevention 8, 35-40.

Zubik L \& Meydani M (2003) Bioavailability of soybean isoflavones from aglycone and glucoside forms in American women. American Journal of Clinical Nutrition 77, 1459-1465. 